\title{
PENGARUH DESAIN KANTIN TERHADAP FLEKSIBILITAS KEGIATAN MAHASISWA UNIVERSITAS MATANA
}

\author{
Calvin R. Octavianus ${ }^{1}$, Louis Alexandra ${ }^{2}$ \\ Program Studi Arsitektur, FSTEM, Universitas Matana ${ }^{1,2}$
}

\begin{abstract}
Abstrak
Kantin adalah salah satu tempat untuk memenuhi kebutuhan makan dalam lingkungan kampus, selain harganya terjangkau oleh mahasiswa tempatnya juga terjangkau yaitu terletak didalam lingkungan kampus. Meskipun harganya murah dan terjangkau namun higiene sanitasi makanan harus tetap di perhatikan. Tujuan penelitian ini adalah mengidentifikasi kondisi higiene sanitasi penjamah makanan di kantin kampus universitas matana, tangerang berdasarkan Peraturan Menteri Kesehatan Republik Indonesia Nomor 1096/MENKES/PER/VI/2011 Tentang Higiene Sanitasi Jasaboga. Selain itu, kantin diharapkan dapat mennjadi tempat menampung kegiatas mahasiswa lainnya, tempat ini dapat fleksibel terhadap segala kegiatan yang dilakukan mahasiswa didalmnya.
\end{abstract}

Kata Kunci : desain kantin, fleksibilitas, pola kegiatan, kampus.

\begin{abstract}
Canteen is one place to meet food needs in the campus environment, besides the price is affordable by students, the place is also affordable, which is located within the campus environment. Even though the price is cheap and affordable, the hygiene of food sanitation must be kept in mind. The purpose of this study was to identify the sanitation hygiene conditions of food handlers in the canteen of the matana university campus, Tangerang based on the Regulation of the Minister of Health of the Republic of Indonesia Number 1096 / MENKES / PER / VI / 2011 concerning Jasaboga Sanitary Hygiene. In addition, the canteen is expected to be a place to accommodate other students' activities, this place can be flexible to all activities carried out by students in it.
\end{abstract}

Keywords : canteen design, flexibility, pattern of activities, campus.

\section{Pendahuluan}

Dalam ruang lingkup perkuliahan, selalu menyediakan lahan untuk berkreasi setiap anaknnya, agar anak dapat berkembang, dan bersosialisasi serta menunjukan bakat yang dimilikinya, maka dari itu, kami ingin mencari riset, apakah kantin di universitas matana, dapat menjadi tempat kegiatan 
mahasiswa dalam berkreasi, selain makan dan minum. Ruang yang dapat fleksibel untuk menampung kegiatan mahasiswa.

Kantin (dari bahasa Belanda: kantine) adalah sebuah ruangan dalam sebuah gedung umum yang dapat digunakan pengunjungnya untuk makan, baik makanan yang dibawa sendiri maupun yang dibeli di sana. Kantin sendiri harus mengikuti prosedur tentang cara mengolah dan menjaga kebersihan kantin.Makanan yang disediakan kantin haruslah bersih dan halal.Jenis-jenis makanan yang disediakan pun minimal harus memenuhi 4 sehat 5 sempurna.Biasanya para pembeli harus mengantri dalam sebuah jalur yang disediakan untuk membeli makanan.

Kantin hampir selalu ada di tiap sekolah di Indonesia. Biasanya kantin menjadi tempat berkumpul bagi para murid. Pesan ambil bayar duduk mungkin merupakan prinsip para pengguna fasilitas kantin. Ramainya kantin disebabkan oleh obrolan siswasiswi yang makan bersama. Kebanyakan murid menganggap penting kantin sebagai tempat bersosialisasi, tempat berkumpulnya seluruh angkatan.

Fleksibelitas adalah kemampuan untuk beradaptasi (adaptif) dan bekerja dengan efektif dalam situasi yang berbeda, dan dengan berbagai individu atau kelompok. Kegiatan mahasiswa adalah wadah aktivitas kemahasiswaan di luar kelas untuk mengembangkan minat, bakat dan keahlian tertentu. Lembaga ini merupakan partner organisasi kemahasiswaan intra kampus lainnya seperti senat mahasiswa dan badan eksekutif mahasiswa, baik yang berada di tingkat program studi, jurusan, maupun universitas. Lembaga ini bersifat otonom, dan bukan sebagai cabang dari badan eksekutif maupun senat mahasiswa.

\section{Metode Penelitian}

Penelitian ini dilakukan untuk mengetahui pengaruh desain kantin terhadap fleksibilitas kegiatan mahasiswa Universitas Matana. Untuk mengetahui ada atau tidaknya pengaruh antara kedua variabel tersebut, dilakukan pengumpulan data dengan metode kuantitatif dengan cara mengadakan kuesioner terhadap 50 responden di Universitas Matana dari Mahasiswa. Data lalu diproses dengan software SPSS untuk menguji validitas dan reliabilitas data dan menguji hipotesis yang meliputi uji korelasi, koefisien determinasi, uji signifikansi, dan persamaan regresi (Sugiono, 2013). Untuk mengetahui pengaruh, hubungan perlu diketahui terlebih dulu (Damayanthi dan Khamdevi, 2015). Berikut Indikator tiap-tiap variable: 


\begin{tabular}{|c|c|}
\hline Variabel X: Desain Kantin & Variabel Y: Fleksibilitas Kegiatan Mahasiswa \\
\hline $\begin{array}{l}\text { 1. Keamanan Pangan: } \\
\text { a. Bahan baku dan tambahan pangan yang aman dikonsumsi } \\
\text { b. Menyimpan produk jauh dari toilet dan tempat sampah } \\
\text { c. Pelayan menggunakan celemek } \\
\text { d. Peralatan masak bersih dan aman } \\
\text { e. Pencucian peralatan dengan air mengalir } \\
\text { f. Penyajian pangan diletakkan pada tempat tertutup } \\
\text { g. Tidak ada benda asing pada produk } \\
\text { h. Pelayan sakit tidak mengolah produk } \\
\text { i. Ruang terhindar dari cemaran } \\
\text { 2. Kehalalan Pangan: } \\
\text { a. Bahan produksi disetujui LPPOM MUI } \\
\text { b. Menu halal } \\
\text { c. Menu tidak memiliki nama yang diharamkan } \\
\text { d. Fasilitas memasak terbebas dari najis } \\
\text { e. Mencuci fasilitas untuk menghilangkan najis } \\
\text { f. Tidak terjadi kontaminasi oleh barang haram/najis } \\
\text { g. Dikhususkan untuk memajang menu/produk halal } \\
\text { h. Melarang pelayan mengkonsumsi produk haram/tidak jelas kehalalannya } \\
\text { 3. Kenyamanan Lokasi : } \\
\text { a. Pelayanan memuaskan Fasilitas kantin memadai } \\
\text { b. Kemudahan transaksi pembayaran } \\
\text { c. Suasana nyaman } \\
\text { d. Tempat berdiskusi dan berkumpul } \\
\text { 4. Harga : } \\
\text { a. Harga produk terjangkau } \\
\text { b. Harga sesuai dengan kualitas produk } \\
\text { c. Harga produk kompetitif } \\
\text { 5. Ada wastafel atau tempat cuci tangan } \\
\text { 6. Pengamanan kantin baik berupa pengamanan keamanan, kebersihan, dan } \\
\text { makanannya. }\end{array}$ & $\begin{array}{l}\text { 1. Keamampuan seseorang untuk mengatasi secara efektif terhadap keadaan- } \\
\text { keadaan yg tengah terjadi dalam masyarakat lingkungannya. } \\
\text { 2. Merupakan keamampuan sesorang untuk dapat melakukan: kebebasan pribadi } \\
\text { (personal independence) dan kemampuan beradaptasi secara pribadi (personal } \\
\text { adaption) --- (Nihira, 1969) } \\
\text { 3. Merupakan kemampuan untuk melakukan: fungsi otonomi (funcutional } \\
\text { autonomy); tanggung jawab sosial (social responsibility); kemampuan } \\
\text { penyesuaian terhadap orang-perorang (interpersonal adjusment) --- (Lambert \& } \\
\text { Nicoll,1976) } \\
\text { 4. Merupakan bentuk kemampuan seseorang yang berkaitan dengan: fungsi } \\
\text { kemandirian (independent functioning) untuk mencapai keberhasilan } \\
\text { melaksanakan tugas sesuai dengan usia dan harapan masyarakat sekitar. Seperti } \\
\text { membersikan diri, menggunakan toilet, makan, berpakaian, bepergian dan } \\
\text { sebagainya. Dan tanggung jawab pribadi (personal responsibility). Serta mampu } \\
\text { memantau perilaku pribadinya dan dapat menerima semua resiko/tanggung jawab } \\
\text { atas pengambilan suatu keputusan: tercermin dalam pembuatan keputusan dan } \\
\text { pemilihan tingkah laku. Tanggung javwab sosaial (social responsibility) seperti } \\
\text { menerima tanggung jawab sebagai angota kelompok/masyarakat dan } \\
\text { melaksanakan tingkah laku yang sesuai dengan harapan kelompok/masyarakat: } \\
\text { penyesuaian sosial terhadap lingkungan, perkembangan emosional, kemandirian } \\
\text { ekonomi, tanggungjawb sebagai warganegara --- (Leland, 1978) }\end{array}$ \\
\hline
\end{tabular}

\section{Hasil dan Pembahasan}

Pengambilan sampel dilakukan di Universitas Matana, dengan target responden mahasiswa Universitas Matana. Pada gambar 1. diatas menunjukan bahwa jenis kelamin responden yang mengisi kuesioner, terdapat 24 laki-laki dan 31 perempuan.

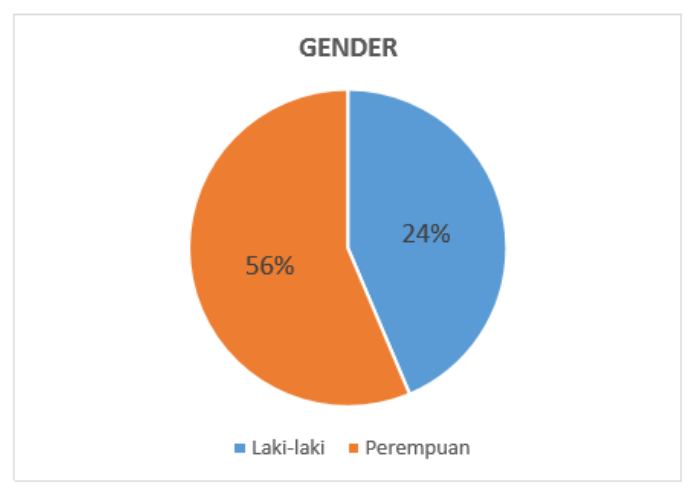

Gambar 1. Perbandingan gender

Pada gambar 2. diatas menunjukan bahwa usia responden yang mengisi kuesioner, mayoritas berusia 18-22 tahun yaitu sebanyak 53 orang sementara sisanya 2 orang berusia 22-32 tahun. 


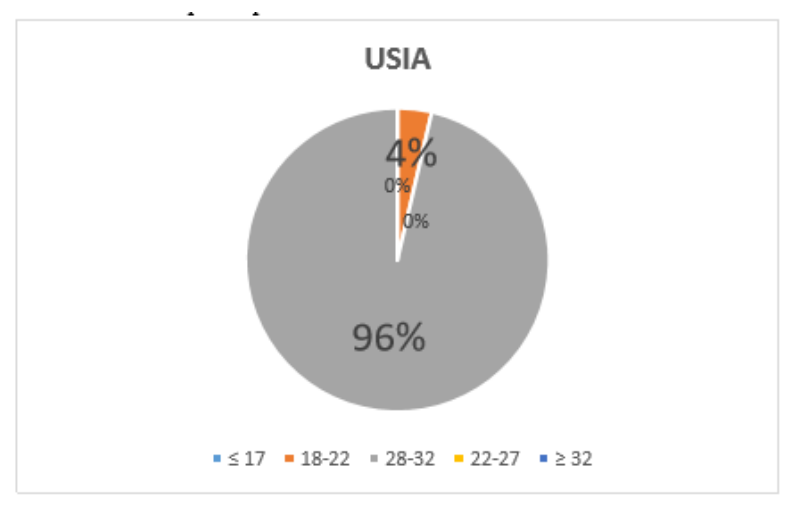

Gambar 2. Perbandingan Usia

Pada Gambar 3. pada pernyataan variable x (kantin) pernyataan ke-1 terlihat bahwa responden terbanyak yaitu memilih ragu-ragu, dan yang paling sedikit adalah sangat tidak setuju bahwa pelayan menggunakan atribut memasak. Pada pernyataan variable $x$ (kantin) pernyataan ke-2 terlihat bahwa responden terbanyak yaitu memilih ragu-ragu, dan yang paling sedikit adalah sangat tidak setuju dan tidak setuju dengan jumlah yang sama bahwa peralatan masak bersih dan aman. Pada pernyataan variable $x$ (kantin) pernyataan ke-3 terlihat bahwa responden terbanyak yaitu memilih setuju, dan yang paling sedikit adalah sangat tidak setuju dan tidak setuju bahwa tidak ada benda asing pada makanan. Pada pernyataan variable $x$ (kantin) pernyataan ke-4 terlihat bahwa responden terbanyak yaitu memilih setuju, dan yang paling sedikit adalah ragu-ragu bahwa menu makanan halal. Pada pernyataan variable $x$ (kantin) pernyataan ke-5 terlihat bahwa responden terbanyak yaitu memilih ragu-ragu, dan yang paling sedikit adalah sangat setuju bahwa fasilitas kantin memadai. Pada pernyataan variable $x$ (kantin) pernyataan ke- 6 terlihat bahwa responden terbanyak yaitu memilih setuju, dan yang paling sedikit adalah tidak setuju bahwa kantin memiliki washtafel/tempat cuci tangan. Pada pernyataan variable x (kantin) pernyataan ke-7 terlihat bahwa responden terbanyak yaitu memilihtidak setuju, dan yang paling sedikit adalah sangat setuju bahwa suasana kantin nyaman. Pada pernyataan variable $x$ (kantin) pernyataan ke-8 terlihat bahwa responden terbanyak yaitu memilih ragu-ragu, dan yang paling sedikit adalah sangat setuju kantin dapat dijadikan tempat berdiskusi dan berkumpul. Pada pernyataan variable x (kantin) pernyataan ke-9 terlihat bahwa responden terbanyak yaitu memilih ragu-ragu, dan yang paling sedikit adalah sangat setuju ruang terhindar dari pencemaran. Pada pernyataan variable $x$ (kantin) pernyataan ke10 terlihat bahwa responden terbanyak yaitu memilih ragu-ragu dan setuju dengan jumlah pemilih yang sama banyaknya, dan yang paling sedikit adalah sangat tiak setuju bahwa tranksaksi pembayaran mudah dilakukan walu dalam keaadaan ramai. Pada pernyataan variable $\mathrm{x}$ (kantin) pernyataan ke-11 terlihat bahwa responden terbanyak yaitu memilih setuju, dan yang paling sedikit adalah sangat setuju, dan sangat tidak setuju bahwa harga produk terjangkau. Pada pernyataan variable $\mathrm{x}$ (kantin) pernyataan ke-12 terlihat bahwa responden terbanyak yaitu memilih setuju, dan yang paling sedikit adalah sangat setuju bahwa harga sesuai dengan kualitas produk. Pada pernyataan variable $x$ (kantin) pernyataan ke-13 terlihat bahwa responden terbanyak yaitu memilih setuju, dan yang paling sedikit adalah sangat setuju, dan sangat tidak setuju bahwa harga produk kompetitif. 


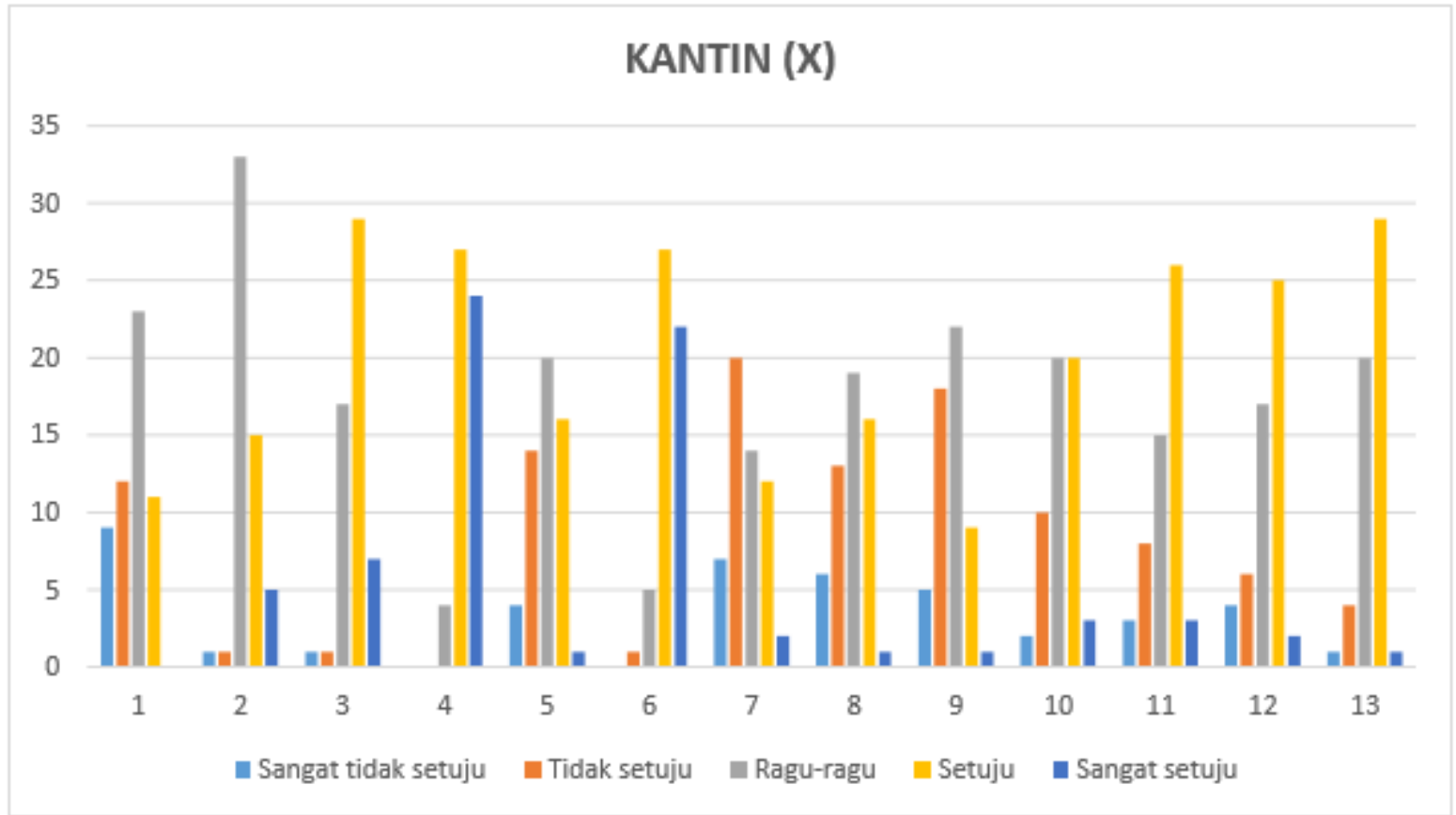

Gambar 3. Grafik Variabel Kantin (X)

Pada gambar 4. pada variabel fleksibilitas $(\mathrm{Y})$ pernyataan ke-1 terlihat bahwa responden terbanyak memilih setuju sebanyak 31 orang, dan responden paling sedikit memilih sangat setuju sebanyak 2 orang bahwa mahasiswa merasa aman saat di Matana. Pada variabel fleksibilitas (Y) pernyataan ke2 terlihat bahwa responden terbanyak memilih setuju sebanyak 30 orang, dan responden paling sedikit memilih sangat tidak setuju dan sangat setuju sebanyak 2 orang bahwa mahasiswa memiliki kebebasan dalam beraktivitas di Matana. Pada variabel fleksibilitas (Y) pernyataan ke-3 terlihat bahwa responden terbanyak memilih setuju sebanyak 34 orang, dan responden paling sedikit memilih sangat tidak setuju, tidak setuju dan sangat setuju masing-masing sebanyak 1 orang bahwa mahasiswa untuk dapat berinteraksi satu sama lain. Pada variabel fleksibilitas (Y) pernyataan ke-4 terlihat bahwa responden terbanyak memilih setuju sebanyak 30 orang, dan responden paling sedikit memilih sangat tidak setuju dan sangat setuju sebanyak 2 orang bahwa mahasiswa mendapatkan ruang gerak yang cukup di Matana. Pada variabel fleksibilitas (Y) pernyataan ke-5 terlihat bahwa responden terbanyak memilih setuju sebanyak 23 orang, dan responden paling sedikit memilih sangat tidak setuju sebanyak 2 orang bahwa mahasiswa merasa nyaman di Matana. Pada variabel fleksibilitas $(Y)$ pernyataan ke-6 terlihat bahwa responden terbanyak memilih tidak setuju sebanyak 24 orang, dan responden paling sedikit memilih sangat tidak setuju sebanyak 0 orang bahwa mahasiswa lebih memilih makan di dalam Matana. Pada variabel fleksibilitas (Y) pernyataan ke-7 terlihat bahwa responden terbanyak memilih sangat tidak setuju sebanyak 25 orang, dan responden paling sedikit memilih sangat tidak setuju sebanyak 0 orang bahwa mahasiswa lebih memilih nongkrong di dalam Matana. 


\section{FLEKSIBILITAS (Y)}

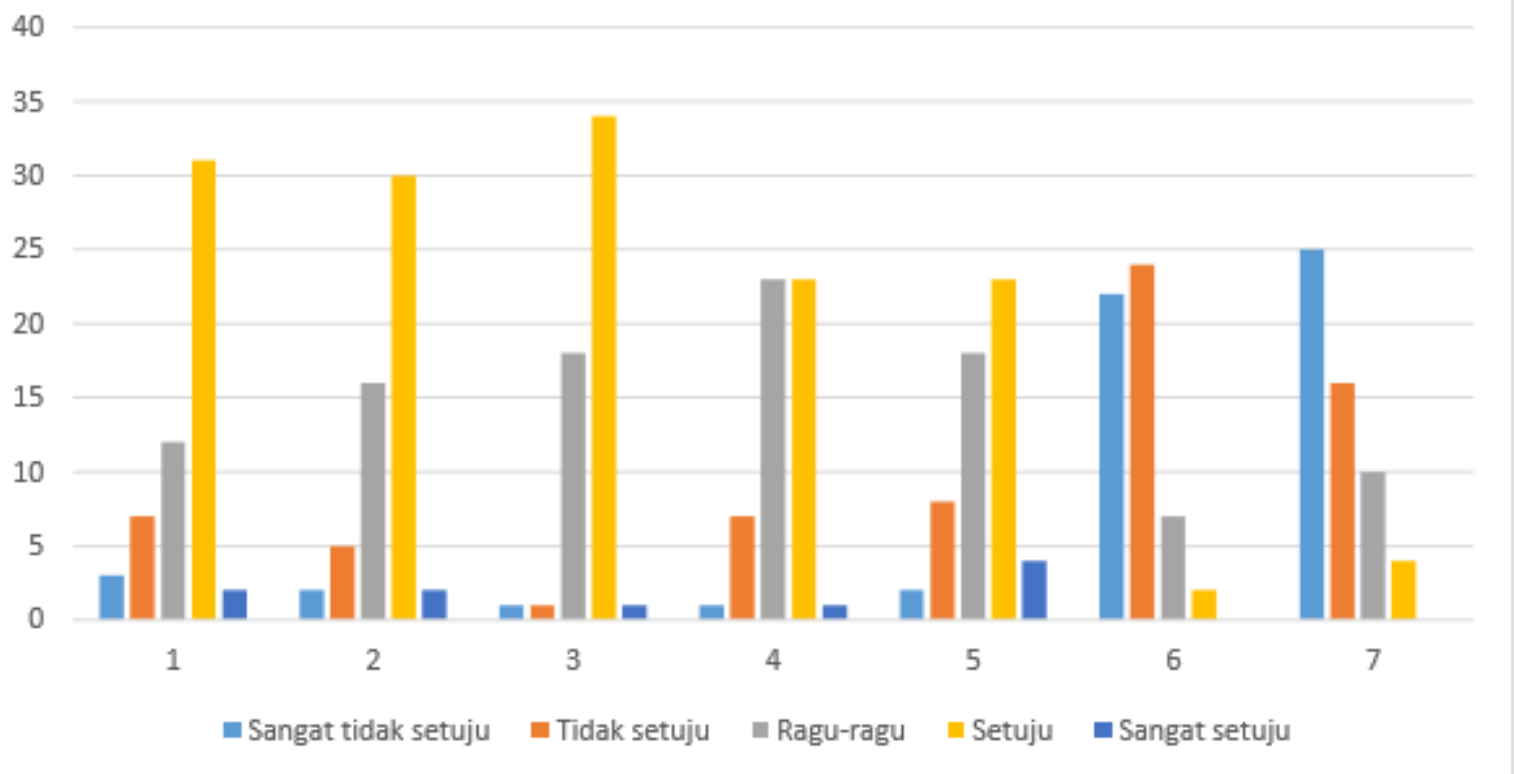

Gambar 4. Grafik Variabel Fleksibilitas (Y)

\section{Uji Validitas}

Uji validitas yang dilakukan menggunakan korelasi Pearson dalam software SPSS. Uji validitas ini bertujuan untung mengetahui apakah setiap pernyataan yang diberikan dalam kuesioner sudah valid untuk mengukur variabel-variabel yang diteliti. Dari uji validitas didapatkan hasil sebagai berikut.

\begin{tabular}{|l|l|l|l|}
\hline Item pertanyaan & $\begin{array}{l}\text { R } \\
\text { hitung }\end{array}$ & R. Tabel & keterangan \\
\hline p1 & 0.493 & 0.224 & Valid \\
\hline p2 & 0.552 & 0.224 & Valid \\
\hline p3 & 0.625 & 0.224 & Valid \\
\hline p4 & 0.298 & 0.224 & Valid \\
\hline p5 & 0.585 & 0.224 & Valid \\
\hline p6 & 0.336 & 0.224 & Valid \\
\hline p7 & 0.598 & 0.224 & Valid \\
\hline p8 & 0.452 & 0.224 & Valid \\
\hline p9 & 0.59 & 0.224 & Valid \\
\hline p10 & 0.399 & 0.224 & Valid \\
\hline p11 & 0.543 & 0.224 & Valid \\
\hline p12 & 0.512 & 0.224 & Valid \\
\hline p13 & 0.249 & 0.224 & Valid \\
\hline xtotal & 1 & 0.224 & Valid \\
\hline
\end{tabular}

Tabel 1. Hasil uji validitas pernyataan-pernyataan variable $[\mathrm{X}]$ 


\begin{tabular}{|l|l|l|l|}
\hline p14 & 0.776 & 0.224 & Valid \\
\hline p15 & 0.636 & 0.224 & Valid \\
\hline p16 & 0.473 & 0.224 & Valid \\
\hline p17 & 0.596 & 0.224 & Valid \\
\hline p18 & 0.708 & 0.224 & Valid \\
\hline p19 & 0.415 & 0.224 & Valid \\
\hline p20 & 0.584 & 0.224 & Valid \\
\hline ytotal & 1 & 0.224 & Valid \\
\hline
\end{tabular}

Tabe1 2. Hasil uji validitas pernyataan-pernyataan variable [Y]

Dari tabel di atas, dapat dilihat bahwa semua data adalah valid.

\section{Uji Reliabilitas}

Pengukuran reliabilitas yang dilakukan menggunakan rumus Cronbach Alpha dalam software SPSS. Uji reliabilitas ini menyertakan seluruh komponen pernyataan pada setiap variable yang 'valid' dan mengabaikan komponen pernyataan yang 'tidak valid'. Dari uji reliabilitas didapatkan hasil sebagai berikut.

\begin{tabular}{|c|c|}
\hline \multicolumn{2}{|c|}{ Reliability Statistics } \\
\hline Cronbach's Alpha & $\mathrm{N}$ of Items \\
\hline .729 & 13 \\
\hline
\end{tabular}

Tabe1 3. Hasil uji relibilitas variabel $[\mathrm{X}]$

Reliability Statistics
\begin{tabular}{l|l} 
Cronbach's Alpha & N of Items \\
\hline 710 & 7 \\
\hline Tabe1 4. Hasil uji relibilitas variabel [Y]
\end{tabular}

Dalam Sujarweni (2012) uji reliabilitas Cronbach Alpha untuk 20 komponen varibel, dan dapat dikatan reliable jika nilai Alphanya lebih besar dari nilai signifikansi tersebut. Lalu, dari tabel di atas didapat bahwa setiap komponen dalam variabel $X$ maupun variabel $Y$ telah riliabel dan dapat dilanjutkan ke tahap penelitian selanjutnya.

\section{Uji Korelasi}

Uji korelasi yang dilakukan menggunakan software SPSS dengan metode koefisien korelasi Product Moment Pearson untuk mengetahui tingkat hubungan antara variable yang diteliti, dimana:

$r_{\text {hitung }}>r_{\text {tabel; }}$ Ho ditolak, Ha diterima $r_{\text {hitung }}<r_{\text {tabel; }}$ Ho diterima, Ha ditolak.

dengan, $\mathrm{Ho}=$ tidak ada hubungan $\mathrm{Ha}=$ ada hubungan . 


\section{Correlations}

\begin{tabular}{llll} 
& & variablex & variabley \\
\hline variablex & Pearson Correlation & 1 & $.505^{* *}$ \\
\cline { 2 - 4 } & Sig. (2-tailed) & & .000 \\
\cline { 2 - 4 } & $\mathrm{N}$ & 55 & 55 \\
\hline variabley & Pearson Correlation & $.505^{* *}$ & 1 \\
\cline { 2 - 4 } & Sig. (2-tailed) & .000 & \\
\cline { 2 - 4 } & $\mathrm{N}$ & 55 & 55 \\
\hline
\end{tabular}

Tabel 5. Uji Korelasi

Berdasarkan hasil perhitungan di atas maka terlihat bahwa koefisien korelasi sebesar 0,505 termasuk pada kategori kuat. Jadi, didapat hubungan yang kuat antara kantin (variabel X) dan fleksibilitas mahasiswa (variabel Y). Terdapat hubungan, namun tingkat hubungan berdasarkan variable adalah sedang.

\begin{tabular}{|c|c|} 
Interval Koefisien & Tingkat Hubungan \\
\hline $0,00-0,199$ & Sangat rendah \\
\hline $0,20-0,399$ & Rendah \\
\hline $0,40-0,599$ & Sedang \\
\hline $0,60-0,799$ & Kuat \\
\hline $0,80-1,000$ & Sangat kuat \\
\hline
\end{tabular}

Tabe1 6.Pedoman untuk memberikan interpretasi koefisien korelasi.

\section{Koefisien Determinasi}

Untuk mengetahui seberapa besar variabel $[\mathrm{X}]$ memengaruhi variable [Y] maka dicari koefisien determinasinya (koefisien penentu) dengan rumus:

$K d=r^{2} \times 100 \%$

Maka $\mathrm{Kd}=(0,505)^{2} \times 100 \% \mathrm{Kd}=25 \%$

Dari hasil perhitungan koefisen determinasi didapat bahawa pengaruh variabel $[\mathrm{X}]$ : desain kantin terhadap variabel [Y]: fleksibilitas kegiatan mahasiswa Universitas Matana hanya sebesar 25\% yang mana sisanya $75 \%$ dapat dipengaruhi oleh faktor lain.

\section{Uji Signifikansi}

Untuk mengetahui signifikansi korelasi antara variable, dilakukan uji signifikansi menggunakan software SPSS dengan metode regresi linear sederhana. Dimana:

$t_{\text {hitung }}>t_{\text {tabel; }}$ Ho ditolak, Ha diterima $t_{\text {hitung }}<t_{\text {tabel; }}$ Ho diterima, Ha ditolak

dengan, $\mathrm{Ho}=$ tidak signifikan $\mathrm{Ha}=$ signifikan 


\section{Coefficients $^{\mathrm{a}}$}

\begin{tabular}{|c|c|c|c|c|c|c|}
\hline \multirow[b]{2}{*}{ Model } & & \multicolumn{2}{|c|}{ Unstandardized Coefficients } & \multirow{2}{*}{$\begin{array}{l}\text { Standardized } \\
\text { Coefficients } \\
\text { Beta } \\
\end{array}$} & \multirow[b]{2}{*}{$\mathrm{t}$} & \multirow[b]{2}{*}{ Sig. } \\
\hline & & $\mathrm{B}$ & Std. Error & & & \\
\hline \multirow[t]{2}{*}{1} & (Constant) & 26.572 & 3.863 & & 6.879 & .000 \\
\hline & variabley & .782 & .183 & .505 & 4.263 & .000 \\
\hline
\end{tabular}

a. Dependent Variable: variablex

Tabel 7. Uji Signifikansi

Dari perhitungantersebut didapat $t_{\text {hitung }}$ sebesar 4.263. Selanjutnya dicari tabel dengan tingkat signifikansi two-tailed 5\% atau sebesar 1,677 untuk 50 responden (Sujarweni dan Endrayanto, 2012). Dengan demikian, $t_{\text {hitung }}$ lebih besar dari $t_{\text {tabel, }}$ maka Ho ditolak dan Ha diterima, artinya terdapat hubungan signifikan antara variabel $[\mathrm{X}]$ dengan variabel $[\mathrm{Y}]$.

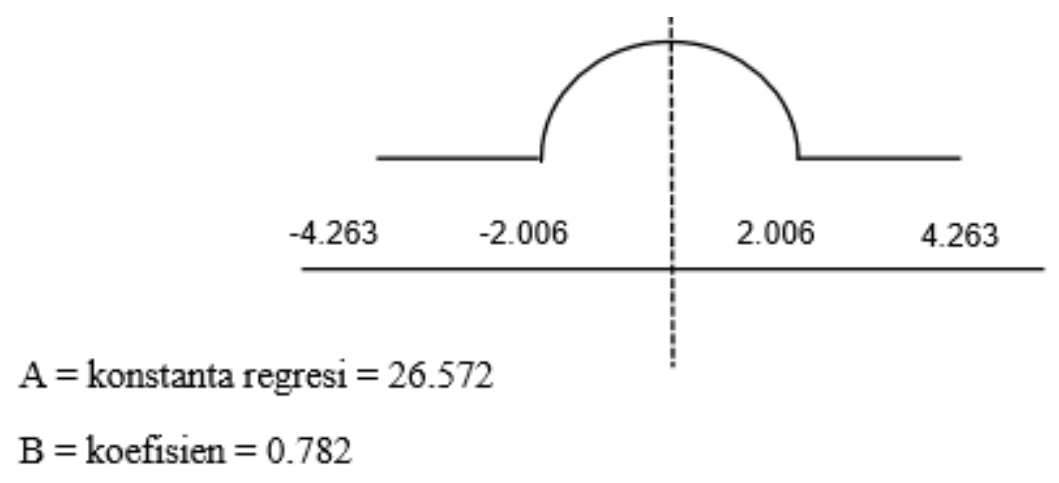

Gambar 5. Kurva Signifikansi Korelasi

\section{Persamaan Regresi}

Selanjutnya untuk melihat seberapa signifikan hubungan antara desain dan kinerja elevator dengan mobilitas pengguan di Universitas Matana, maka dilakukan perhitungan regresi linear sederhana dengan persamaan:

$y=a+b x$

dimana, $a=$ konstanta dependent $b=$ konstanta independent $x=$ variabel dependent

$(\mathrm{X}=0)$

$\mathrm{Y}=27+0.8 \mathrm{x}$

$\mathrm{Y}=27+0.8 * 0$

$\mathrm{Y}=27$

$(\mathrm{x}=10)$

$\mathrm{Y}=27+0.8 * 10$

$\mathrm{Y}=35$

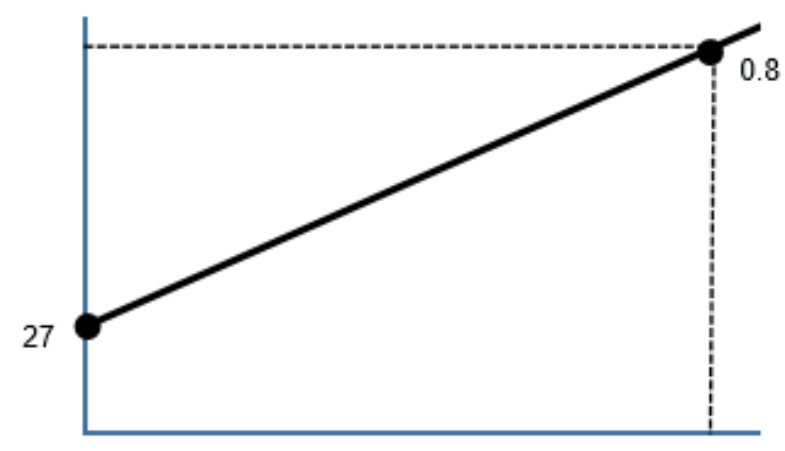




\section{Kesimpulan}

1. Dapat dikatakan bahwa mahasiswa merasa ragu - ragu terhadap keadaan desain kantin.

2. Pola kegiatan mahasiswa di Universitas Matana, sudah cukup fleksibel. Hal ini memengaruhi mobilitas pengguna dalam perpindahan vertikal maupun horizontal di Universitas Matana.

Maka perlu direkomendasikan untuk memperhatikan beberapa hal indikator desain kantin dalam pengaruhnya terhadap fleksibilitas kegiatan mahasiswa, yakni: mengerjakan tugas, melakukan rapat mahasiswa, kegiatan seni dan budaya.

\section{Daftar Pustaka}

Kesehatan Lingkungan. (2012). "Sanitasi Kantin Sekolah". http://kesling.com./sanitasi-kantinsekolah.html\%20(21

Damayanthi, V., Khamdevi, M. (2015). “Pengaruh Setting Peron Terhadap Adaptabilitas Pengguna Krl Studi Kasus: Stasiun Kereta Api Kebayoran Pada Jam Sibuk". Jurnal NalArs Vol 14 No 1. Jakarta: Universitas Mercubuana.

Rohati, Elly. (2012). "Kantin Sekolah Sehat". www.ellyarohati.unair.com

detikHealth. (2012). "Ini dia syarat kantin sehat di sekolah". https://health.detik.com/hidup-sehatdetikhealth/2095891/ini-dia-syarat-kantin-sehat-disekolah

STRATEGI MANAJEMEN. (2010). "Apa Saja Kegiatan Kemahasiswaan Di Perguruan Tinggi?". https://strategimanajemen.wordpress.com/2010/12/11/kegiatan-kemahasiswaan-diperguruantinggi-apa-aja-sih/

Sugiono, (2013). “Metode Penelitian Kuantitatif, Kualitatif, dan R\&D”. Bandung: Alfabeta.

Indosdm. (2008). "Kamus Kompetensi : Fleksibilitas (Flexibility)". http://indosdm.com/kamuskompetensi-fleksibilitas-flexibility

Dwiastuti, Marina. (2013). "KARAKTERISTIK KANTIN SEHAT DAN PENGETAHUAN, SIKAP DAN PERILAKU PARA PEDAGANG TERHADAP CARA PENYAJIAN MAKANAN DIKANTIN KAMPUS "MAKLIA" FAKULTAS KEDOKTERAN UNIVERSITAS HASANUDDIN". https://www.scribd.com/doc/133023870/JURNAL-Kantin-Sehat-Marina-C11107004 